\title{
Exploring the Unexplored Local Own Source Revenue: A Case Study of TMA Murree
}

\author{
Sidra Asif ${ }^{1}$, Abdul Waheed ${ }^{* 2}$, Malik Asghar Naeem ${ }^{3}$, \\ ${ }^{1,2,3}$ National University of Sciences E Technology (NUST), Islamabad, Pakistan
}

\begin{abstract}
Collection of local own source in a decentralized economy is a huge challenge for town administrations in developing countries. The resultant of which is poor service delivery and infrastructural management due to collapses of local economic conditions.In the light of worldwide developed and developing countries scenario this study comprehends the ideology of collection of local own source revenue in Town Municipal Administration Murree and its aftermaths on the local economy.This study has explored all the major sources of revenue in Town Municipal Administration Murree and has identified a clear relation and dependency of internal and external sources of revenue. The research determined that the Town Municipal Administration is mostly dependent on property taxes and financial grants from the provincial government to meet its needs. For unexplored local own source revenues introduction of the property tax in the form of capital gain tax and infrastructure development tax as a major part of the internal own source revenues. For external own source revenue compensation in the form of environmental degradation tax due to positive externalities of the areas tourism capacities should also be introduced. There is no collaboration in the public and private sector for reinforcement of the local economy. It has also been concluded that there is no integrated policy for taxation and revenue generation in the local government.
\end{abstract}

\section{Introduction}

Governments are usually run in a three tier systems globally.Pakistans case is no different; it comprises of Federal government, Provincial government, and Local/Municipal Government (Anjum and Ahmad, 2001). Every government, under given jurisdiction, holds the authority and responsibility to generate and exploit funds efficiently. However efficiency can be a subjective term but in broader perspective it infers to balancing demand supply curves, cash inflows outflows and revenue and expenses.

\subsection{Issues of Local Governments}

The rapid increase in urbanization has created serious trials for local government administrations in both developed and developing countries in terms of environmental contamination, traffic congestion, and lack of affordable housing, poor waste collection, flagging infrastructure and income polarization (Behrens and Robert-Nicoud, 2009). Local governments are required to provide basic infrastructural facilities and appropriate service delivery to their cities. Importantly, the newly rising problem of rapid urbanization has caused urban sprawl marking it to become the biggest challenge for municipalities. It creates difficulties for the

*Corresponding author.

Email: drwaheed@nit.nust.edu.pk local administration to provide means of equal distribution of resources and services to the local residents(Cohen, 2006). An ideal model for service delivery must have a mechanism in which all the services being provided by any local government should be paid back as benefits from those services.However, despite the fact that local communities are willing to pay for the service delivery, they are unable to receive the standard of living they are paying for (Otegbulu and Johnson, 2011). Worldwide studies have been conducted in different local governments to identify the problems in municipal finance.

A case study of municipality of Kllokot, Albania has been encountered during this research which has the similar problem of collection of own source revenue in a local government. The municipality of Kllokot has been very limited in their planning for Own Source Revenues, therefore the department for budget and finance has looked into the possibility of introducing additional sources of revenue and estimation of the capacity building of these sources for revenue generation. The municipality of Kllokot did not have a full property database and had no regular update of the properties levied to the local residents; it was therefore suggested that means to update the property database will enhance collection of local own source revenue. Kllokot can also potentially receive good revenues from con- 
struction permits, geodesic plans and measurements, field inspections of construction sites. Identification of donors and strategic development in terms of tourism and taxation has also led to improvement in the municipal revenue condition (Coudert et al., 2010).

There is a positive relationship between internally generated revenue and infrastructural development in Lagos State Government. It has also been observed that the various methods of generating internal revenue are the enforcement of tax personnel, contribution, and creating awareness to the public and if these are administered correctly they can generate more revenue for the country. The sources of revenue that are significant such as taxes, licenses, fines and fees, grants, financial aids and loans should be reconstructed and re-engineered through public awareness, keeping systematic manner of collection (Adenugba and Ogechi, 2013). The solution for local governments to meet their responsibilities lies largely in the extraction of non-tax revenues and collection of designated local taxes (Pillay, 2015). Local taxes, user charges and fees are a significant local government revenue source, whereas shared taxes are uncommon and borrowing is an insignificant source of finance in most developing SubSaharan African countries (Cohen, 2006). User fees are applied in order to ensure that the municipal finances are being enhanced by the people as per their willingness to pay for any service delivery (UN-HABITAT, 2005).

The local government reform programme (LGRP) in Tanzania has contributed to positive changes in local authorities provision of basic services to the public, enhanced capacity for financial management and revenue enhancement, improved governance, including accountability and responsiveness of the local government (Fjeldstad and Semboja, 2000). The same situation prevails in local governance of Pakistan; Punjab in particular. Many problems have been arising in the decentralized economic revenue collection method. The resultant of which is poor service delivery and infrastructural management due to collapses of local economic conditions. Keeping in view all the worldwide developed and developing countries scenario the current study captures the ideology of collection of local own source revenue in Town Municipal Administration Murree and its effects on the local economy.Generating revenue has been one of the integral problems in any level of governance. For the same reason, the research was to explore major sources of revenue for TMA Murree and identify the existing financial situation. By identification of the source further recommendations of administrative nature have also been proposed. This has led the research to find out dependency of own source revenue of TMA with local economy and then explore the link between internal and external local own source revenue.

\section{Methodology}

Mixed method research methodology has been adopted in this study to create a triangulation of qualitative and quantitative data. For the purpose of research, local economy was segregated into formal and informal economy, focusing on scanning out the sectors under formal tax net from the sectors of economy that has no levied taxes and is not examined by the higher authorities. It is also pertinent to mention here that the activities taking place in an informal economy are not registered in the government economic labels and hence not included in the gross national product or gross domestic product. This type of economy has no rules or fixed wages. People working on daily wagers, hawkers and street vendors, home based entrepreneurs, cobblers, etc. all belong to an informal economy. Therefore, to gauge the financial condition of TMA Murree only formal economy was considered and then revenue sources were assessed to evaluate additional sources of revenues.

The primary data required for this research were collected through the questionnaire based field survey from local community and close observation of collection methods, policy formulations within the TMA and means to implement and monitor these policies. Data and information about socioeconomic and demographic characteristics of the local community were collected through field survey.The sample size designated for this survey consisted of 100 randomly selected households of aforementioned localities of Murree.Basic component of the research was to gather data regarding financial situation of TMA Murree and explore the local own sources which generate revenue for the town. This was carried out through collection of secondary data from the TMA and also by conducting interviews from the people at stake of the revenue collection. Interviews were conducted with the Officers of TMA Murree to understand the method of collection of own source revenue, to get an insight of five year budget and to identify major own source income pattern of the TMA. Furthermore, structured interview of official of Finance department in Punjab Local Government Board office, Lahore to comprehend the process of budgeting and allocation of funds to the case study area from the government department. The data obtained from field surveys including questionnaires and interviews have been analyzed using Statistical Package for the Social Sciences (SPSS). Descriptive statistics techniques have been used to provide central tendency of the data and to explain relationship between different study variables to identify the current financial situation of TMA. Correlation analysis was performed to identify linkages among internal and external sources of income, as well as budget with one another and with the yearly expenditure. 


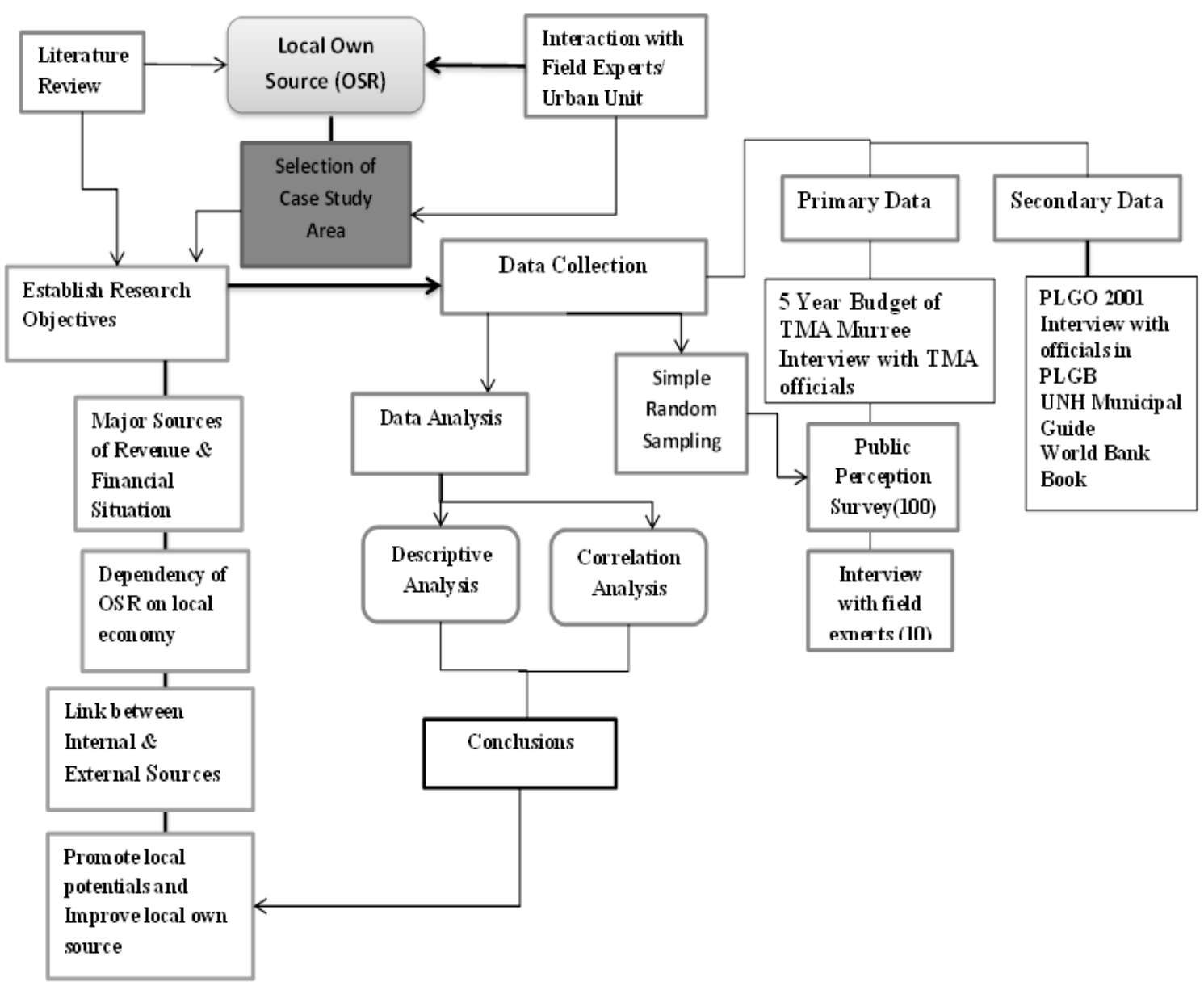

Figure 1: Research Methodology

\section{Results and Discussion}

The results of socioeconomic and demographic analysis of community characteristics show that number of male members in the households is greater than female members $(74 \%)$. However, the result revealed the fact that a large number of households $(80 \%)$ have only one earning member. A large number of the families $(39 \%)$ comprised of 2 male members while only a few $(15 \%)$ have one male member. A few families $(23 \%)$ had more than two male members in their households. Similarly the ratio of female members varied in the households and only a small number of families $(13 \%)$ comprised of one female member, while a huge quantity $(87 \%)$ consisted of two or more than two female members, thus depicting the ratio of female population in the area. The factors highlighted in the socioeconomic characteristics of the residents of TMA are discussed in detail as under. If we examine Table 3.1 we see a variating trend in the type of employment among the residents mostly varied from self-employed to private jobs $(65 \%)$. And only a very few of the residents / bread-earners (35\%) were involved in government jobs or miscellaneous activities (such as caretaker, watchman, shop workers, salesman, etc.)

The monthly income of households has also been identified through different income groups. Almost half of the total sample (49\%) consists of low income group that falls below the average income of 20,000 PKR which depicts urban poverty in the residential units of Murree. Likewise, the other half of the respondents $(48 \%)$ consisted of income groups falling from 20,000 PKR to 60,000 PKR which is considerably a middle income group. This variation also depended largely upon the locations where surveys were conducted thus the trends were different in different areas of the city. The results although indicate that most of the population comprises of lower income class. The ownership trend in the residential areas of Murree has also been discussed in the Table 3.1 where it was observed that more than half of the population (53\%) owned the houses they resided in. Most of the people (42\%) lived on rent. It was also observed that although Murree is a tourist area but only a few (5\%) of people were residing temporarily in the household units. The residents have been settling in Murree for a very long time and a large 
Table 3.1: Socio Economic Characteristics

\begin{tabular}{|c|c|c|c|c|}
\hline Subject Characteristics & $\begin{array}{c}\text { Frequency } \\
\text { (f) }\end{array}$ & $\begin{array}{c}\text { Percentage } \\
(\%)\end{array}$ & Mean & SD \\
\hline Gender of Respondent & 100 & 100 & & \\
\hline Male & 68 & 68 & & \\
\hline Female & 32 & 32 & & \\
\hline Type of Family & 100 & 100 & 1.11 & 0.314 \\
\hline Nuclear & 89 & 89 & & \\
\hline Joint & 11 & 11 & & \\
\hline Single Person & 0 & 0 & & \\
\hline Family Size (Number of Male Members) & 100 & 100 & 1.31 & 0.563 \\
\hline $1-3$ & 74 & 74 & & \\
\hline $4-6$ & 21 & 21 & & \\
\hline $7-10$ & 5 & 5 & & \\
\hline More than 10 & 0 & 0 & & \\
\hline Number of Earning Members & 100 & 100 & 1.2 & 0.402 \\
\hline 1 & 80 & 80 & & \\
\hline 2 & 20 & 20 & & \\
\hline 3 & 0 & 0 & & \\
\hline \multicolumn{5}{|l|}{ More than 3} \\
\hline Employment Type of Earning Members & 100 & 100 & 2.35 & 0.968 \\
\hline Government Job/Army & 18 & 18 & & \\
\hline Self Employed/Shopkeeper & 46 & 46 & & \\
\hline Private Job & 19 & 19 & & \\
\hline Misc. & 17 & 17 & & \\
\hline Monthly Income & 100 & 100 & 1.65 & 0.757 \\
\hline$<20,000 \mathrm{PKR}$ & 49 & 49 & & \\
\hline 20,000-40,000 PKR & 40 & 40 & & \\
\hline 40,000-60,000 PKR & 8 & 8 & & \\
\hline Above 60,000 PKR & 3 & 3 & & \\
\hline House Ownership & 100 & 100 & 1.57 & 0.742 \\
\hline Owned & 53 & 53 & & \\
\hline Rented & 42 & 42 & & \\
\hline Leased & 5 & 5 & & \\
\hline \multicolumn{5}{|l|}{ Other } \\
\hline Stay Period & 100 & 100 & 2.32 & 0.839 \\
\hline$<5$ years & 24 & 24 & & \\
\hline $5-15$ years & 20 & 20 & & \\
\hline $15-25$ years & 56 & 56 & & \\
\hline More than 30 years & 0 & 0 & & \\
\hline
\end{tabular}

number of residents (56\%) have been living in Murree over 20 years. Only a few $(20 \%)$ have been residing in their residential areas for a period ranging from5-15 years and $29 \%$ for less than 5 years.

\subsection{Major Sources of Revenue as per PLGO 2001}

A local government needs to fulfil its role to provide basic amenities in its rural and urban areas in a resilient manner. It has been observed that scarce finances are a major reason of inefficient performance by the local government or any of its concerned TMA. To resolve this issue the fiscal decentralization of local governments was formulated in 2001 and different functions were assigned to the Town Municipal Administrations through Punjab Local Government Ordinance (PLGO) 2001. PLGO 2001 recommends the collection of local own source revenue collection by a town administration which helps it in generating finances from its local sources and taxes levied on the residents in return of utilities, property, etc. This in turn promotes better and efficient financial framework. And only a strong financial government can promote efficient service delivery. The budget allocations and col- 
lection of revenue were major part of the PLGO 2001 and hence it was clearly defined that what kind of taxes and revenues have to be generated by a local government in its area of jurisdiction. These different sources of revenue in TMA Murree from internal and external base are described in the Table 3.2.

\subsection{Dependency \& Distribution of Own Sources}

The income pattern of each own source for a period of five financial years has also been scrutinized from 2009-2010 to 2013-14. The following figure 2 highlights the major sources of income in TMA Murree from 2009 to 2014. This trend helped realize the major sources of income on which the Town Municipal Administration depends. From Figure 2 it is highlighted that during scrutiny of the 5 year income trend it was observed that $21 \%$ of the revenue was being generated from property taxes which is $2 \%$ more than designated in the budget for the same period. It also embarked the fact that there was great potential in revenue generation from this source. However it was also observed that $20 \%$ of PFC had been reserved for the TMA but the same had been utilized up to $26 \%$ which was more than the share of the TMA.

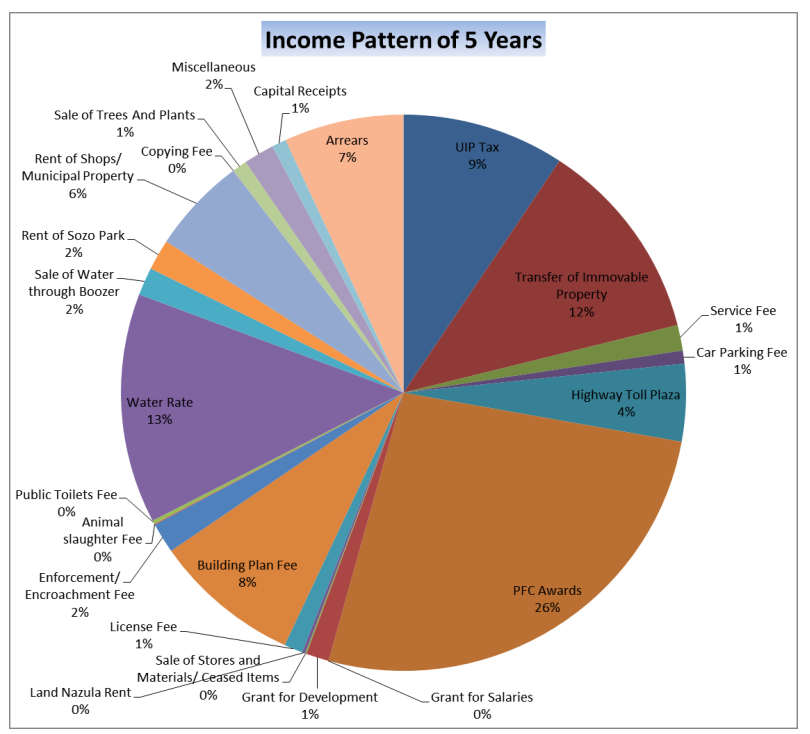

Figure 2: Income Patterns of Past 5 Years in TMA Murree

The Figure 3 describes the total budget trend of 5 years studied to conduct this research. According to this trend a total of $19 \%$ is fixed every year to be collected through property taxes. $20 \%$ is fixed to be collected as PFC grants from the government and $49 \%$ from remaining sources.

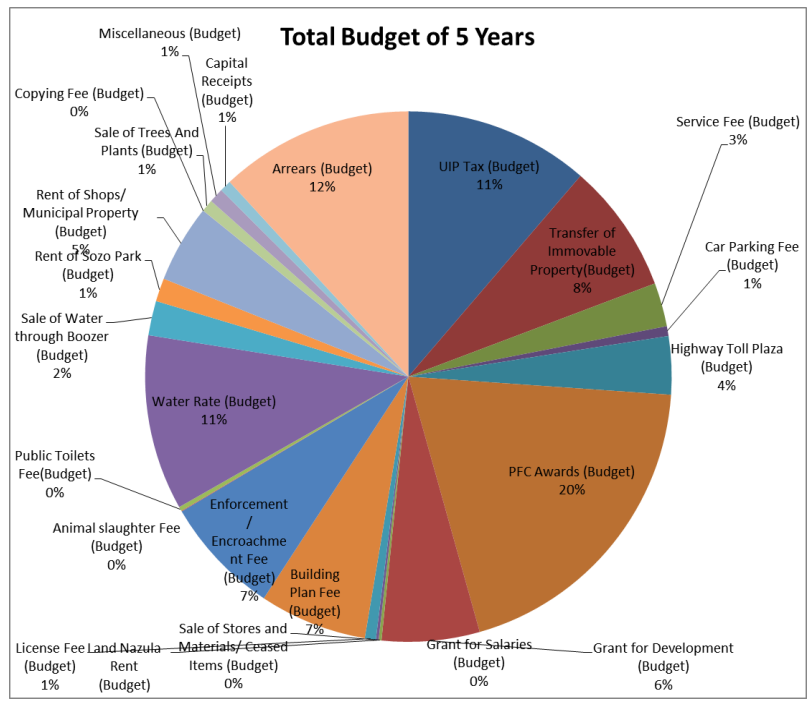

Figure 3: Budget of Past 5 Years in TMA Murree

\subsection{Trend Analysis of Own Source Rev- enue}

Since local economies are of two kinds that are observed in most countries (a) Formal Economy and (b) Informal economy, therefore the revenues are also divided into both these sectors. The formal sector of economy incorporates all kinds of jobs with regular wages. This type of economy involves income sources on which taxes are likely to be paid. People working in different organizations, public sector, schools, bans, etc. all belong to formal economy. Consequently, the external sources of revenues do not really contribute to formal economy, whereas the informal sector of economy has no levied taxes and is not examined by the higher authorities. It is also important to point out that the activities taking place in an informal economy are not registered in the government economic labels and hence not included in the gross national product or gross domestic product. This type of economy has no rules or fixed wages. People working on daily wagers, hawkers and street vendors, home based entrepreneurs, cobblers, etc. all belong to an informal economy. This segregation of documented and undocumented economy is a major concern because when the external entities are being benefitted by the services provided by the local government they are actually contributing to the informal economy of the TMA. On the other hand, in result of the degradation of the infrastructure, government is called upon. The figure 4 shows dependency of own sources on the local economy. Four sources have been identified as major components of formal economy of the local government. These sources are property tax, water rate, building plan fees and rent of municipal properties and shops.

The income generated through these sources is 
henceforth directly reliant upon the local economy. The bar chart in figure 4 reveals that for the year 2009-2010 $13 \%$ of the total income generated was through collection of UIP and TTIP taxes, $11 \%$ was collected through water rate, $10 \%$ through building plan fee and $4.3 \%$ through rent of shops and municipal properties. For the year 2010-2011, it shows that $13 \%$ of the total income for the year was collected through property taxes, $4.9 \%$ through building plan fee and $6.9 \%$ through rent of properties. For the year 2011-2012, 21.17\% of the total income was collected through Property Taxes, $14.6 \%$ through water rates, $7.9 \%$ through Building Plans and $4.9 \%$ by shop and municipal properties rent. For the year 2012-2013, 28\% of the total income was generated from UIP and TTIP taxes, $13 \%$ was collected from Water Rate, $1.49 \%$ was from Building Plan Fees and 6.1\% was collected from Shop Rents. 28\% income was generated from property taxes for the year 2013-2014, 12\% was through water rate, $15.5 \%$ through building plans and $5.9 \%$ from rent of properties.

There has been an increase in the property taxes over the years, the water rate has been somewhat constant for the 5 year income pattern, a massive rise and fall is identified in the building plan fee over the period of 5 years and rent has also been almost the same.

\subsection{Link between External and Internal Lo- cal Own Source}

Regardless of the decentralization of local economy and independent work environment as well as autonomous establishment of each TMA; a huge number of TMAs all over Punjab are mainly reliant on intergovernmental transfer (such as NFC or PFC Awards). This can be deliberated as the reason of inadequate attention to collection of local own sources and means to enhance revenue generation through local own source. However, it is also apposite to highlight the fact that these external sources may also be used to stimulate internally generated revenue through local own sources. The following correlation analysis highlights the link between external and internal sources of income in TMA Murree and also discovers whether the external sources/ grants have a positive or negative impact on the local own source. A Pearson product-moment correlation coefficient was computed to assess the relationship between these variables.

The Table 3.3 describes the correlation among internal and external sources of income as well as budget with one another and with the yearly expenditure.The expenditure trends and internally generated revenue has a positive correlation, where $r=0.976$. This shows that the correlation among these two variables is quite significant, as well as described by the correlation index they exhibit a strong correlation. This is further deliberated with the fact that the increase in expenditure of the TMA stimulates the means to generate more income through internal revenue sources. Similarly, a decrease in the internally generated revenue would cause a negative effect on the development and nondevelopment expenditures within the TMA. Furthermore, the expenditure has a negative correlation with income of external sources, where $r=-0.68$. As per the index of correlation, this represents a strong correlation but with a reverse effect on one another. It means that with the increase in external sources of income (PFC Awards in this case study) the spending on expenditure decreases. However, this study demonstrates that the PFC Award for each year have been nearly static for the past 5 years. And substantially there have been remarkable differences in the expenditure for each year hence justifying the negative correlation.

Table 3.2: Local Own Sources of Revenue in TMA Murree

\begin{tabular}{|c|c|c|c|c|}
\hline \multicolumn{3}{|c|}{ Internal Sources } & \multicolumn{2}{|c|}{ External Source } \\
\hline Land Based & Non-Land Based & Service Charges & $\begin{array}{l}\text { Government Aids/ } \\
\text { Grants }\end{array}$ & Capital Receipts \\
\hline UIP Tax & Car Parking Fee & Community Services & $\begin{array}{l}\text { Share from Highway } \\
\text { Toll Plaza }\end{array}$ & $\begin{array}{ll}\text { Cash Balances by } \\
\text { Local Government/ } \\
\text { Banks }\end{array}$ \\
\hline $\begin{array}{l}\text { Tax on Transfer of } \\
\text { Immovable Property }\end{array}$ & Water Rate & License Fee & PFC Awards & \\
\hline Building Plan Fee & Chair Lift Share & Public Latrines & Grant for Salaries & \\
\hline $\begin{array}{l}\text { Enforcement / En- } \\
\text { croachment }\end{array}$ & Animal Slaughters & $\begin{array}{l}\text { Water Sale through } \\
\text { Boozar }\end{array}$ & $\begin{array}{l}\text { Government Grant } \\
\text { for Development }\end{array}$ & \\
\hline Rent of Sops & Rent of Sozo Park & Copying Fee & & \\
\hline $\begin{array}{l}\text { Rent of Municipal } \\
\text { Property }\end{array}$ & $\begin{array}{l}\text { Sale of trees and } \\
\text { plants }\end{array}$ & & & \\
\hline Land Nazula Rent & Sale of Ceased Goods & & & \\
\hline & Misc. & & & \\
\hline
\end{tabular}




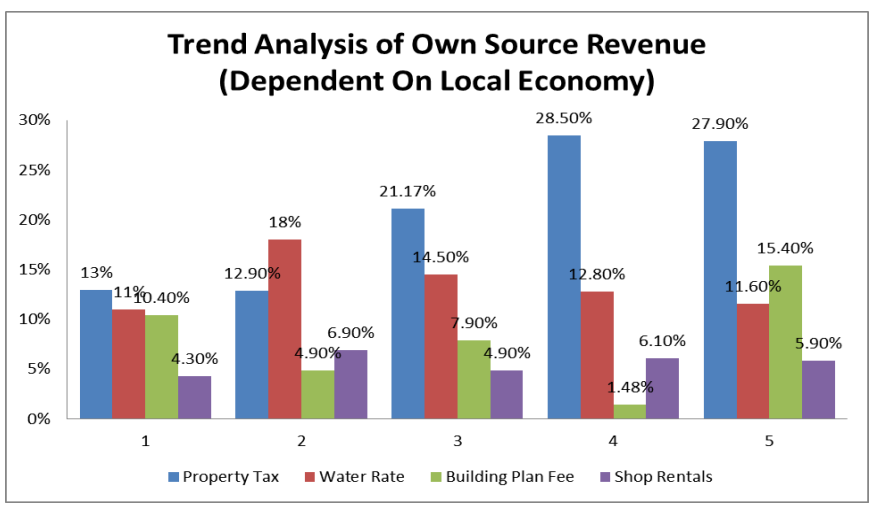

Figure 4: Trend Chart of Own Source Revenue (Dependent on Local Economy

Table 3.3: Correlation Matrix between Internal and External Sources

\begin{tabular}{lccccccc}
\hline Item & Mean & SD & (A) & (B) & (C) & (D) & (E) \\
\hline (A) Expenditure Trend & 1.34 & 4.65 & 1 & & & & \\
(B) Budget of Internal Sources & 1.28 & 6.09 & 0.033 & 1 & & & \\
(C) Budget of External Sources & 3.85 & 7.18 & -0.2 & 0.96 & 1 & & \\
(D) Income of Internal Sources & 7.63 & 1.27 & 0.976 & 0.19 & -0.61 & 1 & \\
(E) Income of External Sources & 3.67 & 5.83 & -0.68 & 0.56 & 0.68 & 0.2 & 1 \\
\hline
\end{tabular}

** Correlation is significant at the 0.01 level (2-tailed)

* Correlation is significant at the 0.05 level (2-tailed)

\section{Conclusion \& Recommendations}

The research determined that the TMA is mostly dependent on property taxes and financial grants from the provincial government to meet its needs.Most of the population belongs to low to middle income groups. The local people are unaware of the importance of taxation and method of collection of taxes.It was also observed during research that the general public is not satisfied with the working efficiency of the Town $\mathrm{Mu}-$ nicipal Administration. There is no collaboration in the public and private sector for reinforcement of the local economy. It has also been concluded that there is no integrated policy for taxation and revenue generation in the local government. The research conducted also led us to the conclusion that to improve revenue generation within the Town Municipal Administration, a few amendments in the overall service structure and financial obligations of the local government can be made. It has also been determined that most of the sources for own source revenue collection have not been reviewed or changed for a very long time and the process of its revision is time consuming and governmental in nature. It was observed that political involvement can also create difference in collection of revenue as local political leaders have an influence on the local people. In the instant research it has been concluded that selfsufficiency can be enhanced through improving the under explored sources of revenue and introducing some new unexplored sources of revenue to strengthen the economy at both and local and national level.

\subsection{Recommendations}

There is a need to balance the operating costs and expenditures on local government levels as well. This imbalance in TMA Murree could be due to a number of reasons but that was not of prime focus in this study, rather, we focused on identification of sources of revenues and based on that, we proposed new local own source revenues for TMA Murree. The following recommendations, if adopted, can resolve the financial imbalance of the local government in Murree. This will lead to economic prosperity administrative efficiency and social uplift in standards of living in TMA Murree. There are a few components that have been highlighted in the research as key factors for improvement of local own source in a TMA:

Public is unaware of the method of taxation and lags trust towards the local government. To rectify this situation hence awareness among the civilians is required.We must educate our taxpayers by providing proper awareness of the importance of taxation. Local council members must be included in the decision making of tax rates and annual budgets as they are well aware of the issues of public. Taxpayers must be registered with the concerned TMA for efficient payment of taxes and information distribution as and when re- 
quired.

An efficient policy must be made at all three tiers of government i.e. local, provincial and national level to improve the revenue generation. It is also important that the policies at all levels must be well integrated and coordinated. The revision and rephrasing of policies has to be done at two levels: inter-governmental and intra-governmental. The TMA should devise a proper management system to compute levied taxes as well as tax database. All stakeholders must be well coordinated and informed about the annual taxation methods as well as change in tax rates. The officials collecting revenue at municipal level must be well trained. With the inflation rates in the annual budget the tax rates should be revised by the government to keep an easy and acceptable tax return from the public.

An electronic system for levied taxes must be introduced. GIS and GPS mapping may also be incorporated with the electronic taxation system for efficient identification of all citizens/taxpayers. Online complaint registration system should be introduced, so that general public can communicate their problems to the government without any hindrance. PublicPrivate Partnership should be introduced in collaboration with local government and concerned local municipality. Outsourcing of private firms (Albayrak, PHA and RWMC in Murree) along with the TMA officials can generate revenue for both the departments. Service based revenue such as service fee, license fee; animal slaughter fee, environmental protection fee, infrastructural development, etc. must be introduced through public-private partnerships. Staff in all the departments must be well aware of their area and jurisdiction and apt training of all the officials must be done after specific intervals of time for efficient working and results from all government and private departments. All the allied departments must be well coordinated. It is therefore necessary that combined workshops and training programs must be designed for all the departments. The most significant factor in improvement of the local own source revenue is the ability of the local government to be self-sufficient. To increase the local own source revenue of TMA Murree the globally adopted approach of linking the services provided to the collected revenue should be adopted. Since everyone wants to see what they are paying for therefore in this way people would be more supportive to pay taxes for a particular service that would certainly be for their own individual and collective benefit.

The research determined that following sources of revenue are under explored within the city and hence efforts should be made by the TMA officials to improve revenue from these sources in collaboration with other departments; if and where required.

- Building Plan Fees

- Rent of Recreational and Commercial Properties
- License and Animal Slaughter Fee

- Fee for Public Services

Similarly, new sources can also be introduced in the TMA as per its potential of generating revenue. The following unexplored sources should be proposed henceforth for improvement of local own source revenue. In the light of the existing property tax situation, property tax in the form of capital gain tax should be imposed because even if the property is not being traded local government is incurring some costs to maintain the area around that property. This compensation on property not being traded for a period of more than, for instance, 10 years should be paid to the local government according to the percentage of capital gain across the property. Any property held or traded has some utilities built around it by the local government to develop that area. That infrastructure development tax could include addition of local parks, street lights, roads, water supplies, sewage systems, etc. into the area. The increase in value of ones property due to increase in infrastructure facilities built by the government should be compensated by the property holder.There should be a compensation fee for the environmental degradation of the area by each and every person coming from outside the jurisdiction of the TMA. Utilizing services built by local government like water supplies, sewerage systems, roads etc. should be compensated for local people by the non-local people to the extent of damage done to the whole system (Fruits, 2015).

\subsection{Future Prospects}

This research can be extended by taking on board the local government and run real time micro systems for particular areas in Murree. The micromodel project would provide proper insight to the functionality and efficiency of the proposed recommendation on real time scales. Furthermore, other areas in Pakistan can be identified with similar geo-socio-economic conditions, where the model can be implemented as well.

\section{References}

Adenugba, A. A. and Ogechi, C. F. (2013). The effect of internal revenue generation on infrastructural development. a study of lagos state internal revenue service. Journal of Educational and Social Research, 3(2):419.

Anjum, Z. H. and Ahmad, N. (2001). New local government system: a step towards community empowerment?[with comments]. The Pakistan Development Review, pages 845867.

Behrens, K. and Robert-Nicoud, F. (2009). Survival of the fittest in cities: Agglomeration polarization, and income inequality. Cahier de recherche/Working Paper, 9:19. 
Cohen, B. (2006). Urbanization in developing countries: Current trends, future projections, and key challenges for sustainability. Technology in society, 28(1-2):63-80.

Coudert, V., Gex, M., et al. (2010). Credit default swap and bond markets: which leads the other. Financial Stability Review, 14:161-167.

Fjeldstad, O.-H. and Semboja, J. (2000). Dilemmas of fiscal decentralisation: A study of local government taxation in tanzania. In Forum for Development Studies, volume 27, pages 7-41. Taylor \& Francis.
Fruits, E. (2015). Impact of federal transfers on state and local own-source spending.

Otegbulu, A. and Johnson, O. (2011). The impact of jacuzzi bathtubs on house prices. Journal of Sustainable Development, 4(3):199.

Pillay, R. (2015). Value of contracting as an active purchasing mechanism of healthcare services: a South African case study. PhD thesis, University of Cape Town. 